\title{
How do histories of survival begin? The incipit as a strategic place of the inexpressible
}

\author{
Licia Taverna \\ Department of French Studies, University of Tartu \\ Ülikooli 17, 50090 Tartu, Estonia \\ e.mail: licia.taverna@tiscalinet.it
}

\begin{abstract}
I analyse here some histories of people who lived in concentration camps and told their experiences: De Gaulle Anthonioz (La Traversée de la nuit), Geoffroy (Au temps des crématoires...), Semprun (L'Écriture ou la vie). These histories represent the lives of survivors, but they are also a form of literary expression with a narrative structure that codifies a genre. More particularly, I focus the attention on the incipit, a strategic place in which some of the specific features of the global meaning and structural organization of the whole text can be seized. My hypothesis is that in histories of survival, already in the incipit, the authors strive to convey the emblematic value of their history: an extreme and traumatic experience which is difficult to express. The analysis of these incipit shows that experiences related to concentration camps, to be expressed, need an elaborated message and that an artistic aim can contribute to the representation of these experiences. From the structural viewpoint, histories of survival amplify a dichotomy existing in several literary genres and currents: 'external reference' and 'internal organization', mimetic 'truth' and narrative 'structure', 'reality' and 'convention', 'experience' and 'narration'. In my opinion, histories of survival solve these oppositions by reconciling some contraries through the use of oxymora. Even narratives structures or key figures such as the author, the narrator, the observer, the witness and so on, tend to become oxymora. The study of these features (and combination) is pertinent for anthropology (by seizing facts thanks to elaborated 'ways of uttering' authors often redefine forms of humanity) and for semiotics (any form of expression, even if original, has to be collectively shared and based on a system of signs). In my opinion, a joint semiotic and anthropological approach can help analysing histories of survival as a 'literary genre' and as a 'historical tragic phenomenon'.
\end{abstract}


Raconter bien, ça veut dire : de façon à être entendus. On n'y parviendra pas sans un peu d'artifice. Suffisamment d'artifice pour que ça devienne de l'art!

Jorge Semprun, L'Écriture ou la vie

\section{Histories of survival as a narrative structure and genre}

In this contribution, I will take into account histories of survival: more particularly, histories of those people who survived the Nazi concentration camps and told their experiences as witnesses to these tragic events. I will concentrate on the semiotic modalities according to which, in these histories, experience is codified (through the filter of memory) and becomes a written text. The semantic universe of histories of survival is often approached by scholars following two 'interpretative styles' which are apparently conflicting: either as a referential message, the analogue of reality that the uttering subject is supposed to record in a purely mimetic form; or as a narrative system that conveys reality thanks to the montage of his structuring elements. In the semiotic perspective that I adopt here, on the contrary, 'referent' and 'narration' are two intertwined components: historical reality is obviously undeniable, even though the textual reconstitution of this same reality can be rendered through multiple narrative shapes.

As a consequence, the semiotic approach is not to be seen as a sort of negation of those terrible events lived by witnesses (events which remain irrefutable and dramatic) or a refusal of the effective and implacable violence of genocide ${ }^{1}$, but as an attempt to seize, through textual analysis, the constitutive features that gather these texts and form this specific genre that is, in my opinion, camp literature. From the semiotic and anthropological viewpoint, the specificity of this genre is the result of the mixture of three fundamental elements: (1) the traumatic experience lived by the narrator-witness, which is in itself unseizable and volatile; (2) the chaotic and fragmentary universe of the memory that recovers, along the time, the event; (3) the

The question of negationism has already been approached, largely and by many scholars, in several publications. See, for example, Ternon 1999 and Coquio (ed.) 2003 . 
codification of events and its communication to the reader. One can say that, in its simpler form, this is a kind of communication that includes an addresser, a receiver and a message. Nevertheless, there is a greater complexity that depends on the semantic structure of the message and this complexity is based on the fact that experience and memory are impalpable and evanescent entities: they belong to the sensitive and cognitive dimensions, difficult to seize in themselves unless they are transformed into a text (written, filmed, drawn, painted, mimed, and so on) which 'contains' prototypically the constitutive semantic features of a specific genre.

In this contribution, starting from these preliminary considerations, I intend to focus the attention on the incipit, a strategic place in which some of the specific features of the global meaning and structural organization of the whole text can be seized. My hypothesis is that in histories of survival, already in the incipit, the authors strive to convey the emblematic value of their story: an extreme and traumatic experience which, if not inexpressible, is at least difficult to tell. The analysis of three incipit will help to show not only the substantial differences existing between three authors, but also to reflect on some structural elements that these incipit have in common.

\section{The conciliation of contraries in the semantic universe of histories of survival}

Histories of survival represent the experience and thoughts of those who lived in concentration camps, but they are also a form of literary expression with its thematic and figurative registers and with its cores of aesthetic constitutions: in a word, they are a real and true genre. In this specific genre, the author function plays a fundamental role. It is elaborated on the basis of a 'structural oxymoron' that associates the 'author of a text' and the 'subject of experience': on the one hand, we can find an 'author' who tries to cancel the traces of his presence (to say that better, the traces of the uttering author) to install the 'subject' himself who lived the traumatic experience and also to communicate the experience as exactly as it was felt; on the other, we see an author who reappears — voluntarily or involuntarily — in the shaping of the 
complex stratification of the text ${ }^{2}$, a shaping and stratification that are sometimes very refined and show the 'artistic nature' of the message seeming in this way to evacuate its referential function. By this mechanism, a very subtle relationship is established between the sensitive material that constitutes the primordial 'substance' of these testimonies (that tend to manifest themselves as referential stories of events) and the artistic system of signs (anyhow conventional and upon which the uttering of the history of survival is built).

An example of the intertwining of the 'literary' and of the 'nonliterary' (the 'artistic text' and of the 'testimonial document') is $L^{\prime}$ Écriture ou la vie by Jorge Semprun $(1994)^{3}$. In this text, the subject of the traumatic experience who relives his past and tells his life in the camps (trying to convey what happened 'as exactly as it happened'), mingles with the author who makes an extremely refined montage of these events:

Il n'y a qu'à se laisser aller. La réalité est là, disponible. La parole aussi.

Pourtant, un doute me vient sur la possibilité de raconter. Non pas que l'expérience vécue soit indicible. Elle a été inévitable, ce qui est toute autre chose, on le comprendra aisément. Autre chose qui ne concerne pas la forme d'un récit possible, mais sa substance. Non pas son articulation, mais sa densité. Ne parviendront à cette substance, cette densité transparente que ceux qui sauront faire de leur témoignage un objet artistique, un espace de création. Ou de recréation. Seul l'artifice d'un récit maîtrisé parviendra à transmettre partiellement la vérité du témoignage. Mais ceci n'a rien d'exceptionnel : il est arrivé ainsi de toute les grandes expériences historiques. (Semprun 1994: 25-26)

2 See, for example, White 2006 (and more particularly the chapter 6: 125-138) a work in which the author analyses Se questo è un uomo (Primo Levi 1963) and shows the poetic nature of the text, even though Levi tried to «manifest the scientific objectivity» of his writing.

${ }_{3}$ In 1943, Semprun was arrested by the Gestapo because he was a member of the French resistance. He was then sent to the concentration camp of Buchenwald as a political prisoner. He was kept in the camp until 1945. After his liberation he remained silent for years until when, in 1963, he publishes Le Grand voyage, his first 'testimony' telling his tragic experience. Dans L'Écriture ou la vie, written fifty years after he gained freedom, his intention was not only 'to tell the events' but 'to make people understand', by using literary devices, what really meant to live in the camps. 
On the basis of a poetic device, Semprun elaborates a complex shaping of involuntary memory which is introduced in the narration in an intermittent, fragmentary and disorderly way: the minute fragments of memory relative to the detention in the camps (and sometimes preceding the life in the camps) are inserted in the linear course of narration (which starts textually from his liberation from the camp) in the form of small and loose notes. Each of these fragments of memory is recalled to mind thanks to meetings, objects, sounds, smells, looks, and whatever else can be attributed to the sphere of phenomenological experience. These 'mnemonic notes' find their musical echo in successive returns where they are recovered starting from the same linguistic syntagms previously used, sometimes with slight changes and with further developments or with gradual and progressive reformulations:

Le temps a passé, Halbwachs était mort. J'avais vécu la mort de Halbwachs.

Mais je ne voulais pas vivre la mort de ce Juif hongrois que je tenais dans mes bras, quelques mois plus tard, un jour d'avril 1945. Je supposais qu'il était hongrois, du moins. Son matricule en tout cas [...] laissait supposer qu'il faisait partie des convois de Juifs en provenance de Hongrie. (Semprun 1994: 63, my emphasis - L. T.)

Mais je ne veux pas vivre la mort de ce Juif anonyme, peut-être hongrois. Je le tiens dans mes bras, je lui parle doucement à l'oreille. (Semprun 1994: 66, my emphasis - L. T.)

In this way, a sort of repetitive symphony is created: an articulated cognitive paradigm of memory is shaded and gradually modulated by its projection on the narrative syntagm. This first shaping of free and involuntary memory is further complicated by an interplay of two different kinds of memory: the first one is older and relative to the detention in the concentration camps; the second one is more recent and rendered in the present by a narrator 'who says what he's seeing and who feels what he's uttering', a memory that refers to the period following his liberation ${ }^{4}$. In other terms, Semprun recomposes his past and recalls its traces spread in his memory through a subtle stylistic research. Nevertheless, this cannot be considered as a research of

4 This more recent memory remains anyway a literary device since the liberation of Semprun dates back to 1945, while the author writes his text many years later, in 1994. 
'aesthetic beauty', but rather a 'rhetorical effect', a specific strategy that the 'testimonial document' conveys through the balanced regulation of the power of uttering.

The co-occurrence of the figure of the author and of the figure of the witness is accompanied by another conciliation of contraries structurally inscribed in these texts: the 'personal vicissitudes' and the 'collective facts'. In effect, the author would like not only to cancel his 'literary' intrusion to leave the experience of the witness in the foreground, but he would also like to diminish the value of his personal experience to better represent the whole community who lived his same tragic events. An exemplary and extreme case of the co-presence of the single individual who dissolves himself into the community is the one represented in the volume $A u$ cour du système concentrationnaire nazi (Sachso 1982), in which the author, if it can be defined as such, is the community: more precisely the Amicale d'Oranienburg-Sachsenhausen abbreviated with the acronym Sachso. In this collective volume, 'truthfulness' passes through the voice of a collective figure represented by an association of survivors (the Amicale):

Au-delà de ce que chacun peut relater de son expérience personnelle, seul un ouvrage collectif comme celui-ci est susceptible, pensons-nous, de donner une approche globale de la réalité vécue par les Français. (Sachso 1982: 7)

In other words, the individual experience is effaced to the advantage of the experience of the community; the single individual voice - the voice of all the individuals who speak and tell the same facts - is effaced before the collective voice which is raised to the unison: a reiterated and obsessively repetitive act of parole that is apparently devoid of an author who, for this same reason, seems to acquire the paradigmatic features of 'impersonality', 'evidence of facts', 'objectivity' and of a 'real and true representation'.

This strategy leads to a third and extremely important question. The 'truthfulness' of the histories of survival is accompanied by a semantic of the non-possible and non-descriptive. The words used by the authors are various: 'inexpressible', 'unnamable', 'indescribable', 'unthinkable', 'unbelievable', 'unimaginable' (to refer to a term dear to Robert Antelme): 
Comment nous résigner à ne pas tenter d'expliquer comment nous en étions venus là ? [...] Et cependant c'était impossible. À peine commencions-nous à raconter, que nous suffoquions. À nous-mêmes, ce que nous avions à dire commençait alors à nous paraitre inimaginable. (Antelme 1948: 5)

In these lines, even though he uses opposing terms (to give up $v s$ to try; to explain $v s$ to experience; impossible $v s$ possible; starting to tell $v s$ to keep on telling; to say $v s$ to suffocate; imaginable vs unimaginable), Antelme does not resign himself to silence and speaks in order to try to solve these semantic (and existential) conflicts. These few lines by Antelme are representative of a whole literary genre and give an idea of this new form of uttering created by authors of histories of survival. In effect, even though it does not reach the same semantic density, camp literature is written in oxymora in which the 'inexpressible is nothing more than what is effectively expressed'. The 'inexpressible' - the 'expressed that cannot be expressed', corresponding very often to the affirmation of powerlessly and thanks to which pass the (im)possibilities of language itself — is part of these semiotic modalities through which texts of survival are made. ${ }^{5}$

Before analysing the incipit of three authors, I briefly summarize the oppositions upon which lays the structural organization of histories of survival: (1) the 'non-literary code' and the 'literary code' (that is what is told as a purely referential plot of events and the artistic component of 'telling the truth'); (2) the co-presence of the experiencing subject and of the author of the text (3) the dissolution of classical frontiers between personal identity and collective identity and the constitution of a constant parallel between an individual (who is inscribed in the text with an ample gamut of emotions and recalling of facts) and the prototype of an entire community represented by an individual spokesman; (4) the emotional and cognitive impossibility to express the experience of horror and death and the infinite expressive possibilities of language. In my perspective, to analyse histories of survival means to concentrate above all in the new forms that the imbrications of these 'structural oxymora' take up: referential story

\footnotetext{
5 On this subject Rinn affirms that «La pratique de l'indicible [est] l'expression d'une stratégie discursive. [...] cet indicible-là, en tant que technè, recherche l'adhésion du récepteur en textualisant un "impossible persuasif". [La] vérité ontologique [de la réalité] ne se qualifie pas à l'aide d'une hiérarchisation axiologique extérieure — objective — , mais en termes de perfectionnement d'une réalité subjective mise en scène» (Rinn 1998: 271, 272).
} 
and artistic component, experience and narration, individual and community, impossibility to tell the inexpressible events and reiterated expression of these events.

\section{The inexpressible as spectacles of the 'Self' and the 'Other' in L'Écriture ou la vie}

The incipit of a literary text is a strategic place due to the fact that the foundations of developing the plot and building the characters are already laid, though in a seminal way, in this small part of the text that produces furthermore an inevitable rupture between the 'real world' and the 'fictional world'. The incipit of histories of survival take up an even more emblematic value since these texts are the report of a real event and characters are men and women who effectively lived the experiences they related. In these incipit one can find, in a succinct and condensed way, some central mechanisms of signification, important uttering strategies and the rhetorical devices used to introduce the reader into the spatial and temporal universe of the inexpressible, the centre of emotional and physical hell, the concentration camps, where the 'witness' was forced to live. In this sense, the incipit of L'Écriture ou la vie by Semprun is striking. In the first two lines, the author tries to communicate the feeling of abandonment and the feeling of loss that is characteristic of experiences concerning concentration camps:

Ils sont en face de moi, l'œil rond, et je me vois soudain dans ce regard d'effroi: leur épouvante. (Semprun 1994: 13)

The sense of loss and the sense of self-identification do not have their origin in the Self of the narrator, but both pass through the look of the Others. The common features of these two opposed movements regarding the meaning of identity are terror (l'effroi) and fear (l'épouvante). In a few lines, the narrator summarizes one of the most important questions for human beings: the definition of Self in conditions of extreme adversity and outside his possibilities. Notwithstanding the inconceivable conditions of existence in the camps, the affirmation of identity is realized here through the co-presence of the author with the "trois officiers, en uniforme britannique" (Semprun 1994: 14), in the look that concentrates on the detail of the round eye, 
an eye that is reduced to two feelings: terror and fear. Due to the absence of the constitutive features that normally determine the sense of identity, the only anchorages remain volatile details and fleeting feelings. The Self (je) of the narrator disappears in the apparent confrontation with the officers (ils) in British uniforms and the sight of the Others is transformed into the levelling of the full presence and the presentation of a weak return to the Self. ${ }^{6}$

This text is so effective because it begins without a real beginning, because it gives some pieces of information on the identity of an individual through the representation of his annihilation. The narrator does not give any narrative anchorage concerning the events going on, he does not situate this representation temporally and spatially, but he restrains the narration to the foregrounding of a confrontation between the Self and the Other. This confrontation - which, according to the rules of the genre, is not a real confrontation since the people who are confronting the narrator are there to free him from prison - is in effect a disintegration of personal identity. It does not become, for this reason, a total affirmation of a collective identity. The only remaining way for the author to see himself is in the bewildered look of the Other. In this way, beginning and non-beginning, confrontation and liberation, representation and annihilation of identity are meeting in the form of narrative and structural oxymora. In these few lines, one can find a dialectics of the affirmation and refusal, the oxymora of presence-absence, the presentation and dissolution of a look that instead of being an instrument of knowledge becomes the only kind of observation of the Self.

In this incipit, some essential questions intermingle powerfully: to represent oneself without forgetting the others, representing oneself concretely even though survivors are physically and mentally unrecognisable, deprived of their identity. One can say that the absence (the "without" that is not always present grammatically) is a structural, latent element that takes on the most different shapes in the

\footnotetext{
6 This return on the Self through the look of the Other is recurrent in the text and used to define, in a transitive and reflexive way, the identity of the narrator. More particularly, the uncertain and suffered identity of the narrator is seized thanks to all different kinds of look and people. For example, the look of the officers in British uniforms is compared with the look of the narrator's friends in the concentration camps, Maurice Halbwachs while dying, the Germans soldiers and, even if paradoxical, tens of corpses.
} 
narrative manifestation of L'Écriture ou la vie and, more generally, in the camp literature. This "without" is only a preposition, but it is an important preposition because it can indicate either imposition or indetermination ${ }^{7}$. 'Indetermination' can be considered positively as the core starting from which one defines the different realizations of the forms of humanity: all forms that are not hierarchically ordered, but equal without exceptions.

At the same time, the opposed pole, the 'imposition' of a form of humanity onto the others (and, as a radical consequence, 'extermination'), produces violence and injustice. This second conjugation of humanity is obviously to reject ideologically, but it is also to study anthropologically for the simple reason that it manifested itself historically defining some conditions of human resistance (in the concentration camps) and a negative idea of the principle of humanity. This anthropological reason (the definition of man in positive and in negative) has to be coupled with a semiotic reason and research: how can a narrative text represent the identity of a man who lived in inhuman condition? And how can a written text convey something that is belonging to the order of the inexpressible? If, more particularly, we refer to L'écriture ou la vie, the preposition "without" becomes a vaster narrative device: it does not only define a clear and strong opposition between the privation and the acquisition, the nonaccomplishment and the accomplishment, but it represents the syntagmatic deployment of a process and a temporal becoming. This becoming is the becoming (of the identity) of the narrator-witness who passes through the corporeal breaking up and the mirror of the Other. The following scene illustrates this hypothesis:

Depuis deux ans, je vivais sans visage. Nul miroir, à Buchenwald. Je voyais mon corps, sa maigreur croissante, une fois par semaine, aux douches. Pas de visage, sur ce corps dérisoire. De la main, parfois, je frôlais une arcade sourcilière, des pommettes saillantes, le creux d'une joue. J'aurais pu me procurer un miroir, sans doute. On trouvait n'importe quoi au marché noir du camp, en échange de pain, de tabac, de margarine. Même de la tendresse, à l'occasion.

Mais je ne m'intéressais pas à ces details. (Semprun 1994: 13)

According to Coquio, the "spectre de l'humain passe [...] par ces deux pôles extrêmes: l'un positif et utopique, qui possibilise sans fin l'humanité à travers l'idée d'indétermination, l'autre négatif et historique, qui réalise sans fin l'inhumanité de l'extermination" (Coquio 1998: 385). 
The "without" is present in the text grammatically, but its meaning is also manifest in the text as a narrative strategy that realizes more largely the sense of privation. It is thanks to this strategy that a close relationship is created between the flowing time and the thinness of the body of the narrator, between the 'totality' of the concept of identity and the 'details' which compose its figure. The privileged focus on the face of the narrator (compared to rest of the body), the face of the Other as a mirror, the mirror as an element of identity are all features which characterize this passage. The shaping of the textual form is very refined. On the one hand, the narrator focuses on the details of the body, on his fragmentation in parts; on the other, he says that he is not interested in details and that he does not want to get a mirror. Between the two first lines and this passage there is a strong difference. In the first two lines, the narrator does not give temporal and spatial indications, while in this passage he starts narrating what happened in Buchenwald, in the concentration camp.

If the reflex in the look of the Other is the effect of an event that is belonging to the order of the inchoative, in the following passage the 'life without face' of the narrator takes place in the durative of the years passed in Buchenwald. This aspectual difference between the inchoative of the beginning and the durative of the following passage opens a series of possible interpretations. For example, one can think of the narrator's desire to communicate the feeling of estrangement and displacement that the face of the Other produces every time on the narrator-witness. One can also advance the hypothesis that the opposition between the inchoative and durative tends to represent the impossibility to get used to fear and terror generated in the concentration camps. Did survivors get used to what was inconceivable and to what was unthinkable? More than a confirmation to an interpretive path, what is important here is Semprun's use of a refined narrative strategy which consists in a bipolar process: affirming and denying, aggregating and breaking up. If, for example, the look (onto the Other and from the Other) has an important place in this beautiful page by Semprun, the body also plays a central role, thanks to the sense of touch. The narrator says that he could have gotten a mirror, but he did not do it. He manifests the precise desire to see himself in the look of the Other: he wants the others to be a reflection of his situation. Furthermore, he is not interested in the details of his body or to look, by a mirror, to the changes of his body. Nevertheless, these changes 
are attracting his attention and he is observing them through the sense of touch, a sense that is giving him an indirect perception of the corporeal process:

Je voyais mon corps, de plus en plus flou, sous la douche hebdomadaire. Amaigri mais vivant : le sang circulait encore, rien à craindre. Ça suffirait, ce corps amenuisé mais disponible, apte à une survie rêvée, bien que peu probable.

La preuve, d'ailleurs : je suis là. (Semprun 1994: 13)

The body, as an inseparable complement of the 'I', a natural completion of the identity, is blurred more and more, until it becomes a "flou", and starts living a life of its own ("amaigri mais vivant", "amenuisé mais disponible", "apte à ..."), as if it was a detached appendix isolated on purpose to underline the loss of identity. At the same time, this body reduced to an organ without soul is also the reaffirmation, even if weak and subdued, of some kind of survival: "une survie rêvée". This loss and reaffirmation of identity is revealed by a narration that foreshadows both an omnipresent subject and the presence of the others, the body of the subject and the look the others.

On the other hand, this implicit intention of the author is confirmed by the title of the first chapter of L'Écriture ou la vie, that is Le regard, a look that is declined according to different typologies (terrorized, scared, fraternal, disgusted, hated, etc.), each of them takes on a precise function for the shaping of the concept of identity:

Ainsi, paradoxalement, du moins à première et courte vue, le regard des miens, quand il leur en restait, pour fraternel qu'il fût - parce qu'il l'était, plutôt - me renvoyait à la mort. [...] Notre être était défini par cela : être avec l'autre dans la mort qui s'avançait. [...] Nous tous qui allions mourir avions choisi la fraternité de cette mort par goût de la liberté.

Voici ce que m'apprenait le regard de Maurice Halbwachs, agonisant.

Le regard des S.S., en revanche, chargé de haine inquiète, mortifère, me renvoyait à la vie. Au fou désir de durer, de survivre [...]

Mais aujourd'hui, en cette journée d'avril, [...] à quoi me renvoie-t-il, le regard horrifié, affolé, des trois officiers en uniforme britannique ?

À quelle horreur, à quelle folie ? (Semprun 1994: 39)

Car il n'y avait pas de survivant [...] Les regards étaient tournés vers nous [...] souvent au prix d'une violente torsion du cou. Des dizaines d'yeux exorbités nous avaient regardé passer.

Regardés sans nous voir. 
Il n'y avait plus de survivants, dans cette baraque du Petit Camp. Les yeux grands ouverts, écarquillés sur l'horreur du monde, les regards dilatés, impénétrables, accusateurs, étaient des yeux éteints, des regards morts. (Semprun 1994: 41)

In practice, the indirect look is an adequate and necessary instrument for the acquisition of the knowledge of Self and Other. By the puzzle of the look and the intermittent memory (both privileged for the reconstruction of experience and situations lived in the camps), Semprun creates a sort of 'window' through which one can observe the horror that took place in the camps and through which the look of the implied reader passes. In this way, the difficult obstacle of the 'inexpressible' experience is overcome by Semprun thanks to the paved passage of the 'visible'. The possibility of the testimony is subjected to the verification of the look that takes on the function to make tangible what can be possibly said and expressed. The resulting hypothesis (that should be investigated in other histories of survival) is that the ellipsis of seeing entails an inevitable fall of the possibility to express (and say) the concentration camps and the survival. More generally, the whole semantic universe of histories of survival should be tested in order to see what are the relationships between the discursive order of the transitive look and the reflexive look, between the expressible and the inexpressible experience, between the seeing and the saying.

\section{Loss and reaffirmation of identity} in La Traversée de la nuit

The analysis of the text written by Semprun has shown that an experience to be expressed needs an elaborated message whose artistic aim can contribute to the representation of this expression: the more the experience is inexpressible, the more we need a refined strategy; the more we want to communicate a deep feeling of estrangement, the more the inexpressible has to take an appropriate form. Nevertheless, if the expression of an identity passes in Semprun through the 'manufacture' of a look (and the breaking up of a body), it is also important to wonder how, more generally, life in concentration camps and the sense of identity of other authors are represented. Even though 
the narrative strategy used by Semprun is powerful, experience in concentration camps is not limited to his 'model'. To show some differences, I have chosen the beginning of La traversée de la nuit de Geneviève De Gaulle Anthonioz (1998) ${ }^{8}$, a text in which an estrangement of the subject is underlined spatially and focusing on the overcoming of a frontier, which is represented by the door of a prison cell:

La porte s'est refermée lourdement. Je suis seule dans la nuit. À peine ai-je pu apercevoir les murs nus de la cellule. En tâtonnant je trouve le bat-flanc et sa couverture rugueuse et m'y allonge en essayant de renouer avec le rêve interrompu : tout à l'heure je marchais sur un chemin éclairé par la lune, une lumière si douce, si bienfaisante, et des voix m'appelaient. Soudain il n'y eut plus que le faisceau d'une lanterne, le visage effaré de notre chef de baraque, l'ordre rauque de me lever et l'ombre de deux SS. Cauchemar ou réalité ? Baty et Félicité, mes voisines de paillasse, se sont réveillées. Elles ont rassemblé quelques objets, dont mon quart et ma gamelle, m'ont aidée à descendre du châlit, m'ont embrassée. Quel sort m'attend? Il arrive que les exécutions aient lieu ainsi de nuit.

Pour le moment, je suis dans un bâtiment à l'intérieur du camp de Ravensbrück, appelé bunker. C'est une prison qui sert aussi de cachot. (De Gaulle Anthonioz 1998: 9-10)

In this initial passage, the narrator stages, ever since the first instants of his narration, the loss of the subject before an incomprehensible reality characterized by the sudden sense of closure and the noisy door, the expression of solitude connected to the impossibility of seeing, the blinding light, the scared look of the chief, the soldiers similar to shadows in the night. These are altogether a series of elements that underline a cognitive loss in the subject. This feeling of loss is suggested (and even conveyed) to an astonished and disoriented reader who, at least initially, does not realize what is going on and what the character is doing and suffering. In effect, the narrator mixes

8 De Gaulle Anthonioz, young resistance member and nephew of De Gaulle, was arrested in 1943 in a library, in Paris, because she was carrying illegal identification cards. She will spend six months in a prison in Fresnes, before being transferred to the concentration camps of Compiègne and then, definitively, to the camps of Ravensbrück. There, after a year of suffering she was imprisoned in a bunker of the camp because Himmler wanted to use her to negotiate with De Gaulle. She was freed in 1945. In La Traversée de la nuit, De Gaulle Anthonioz chooses to tell only the last three months of her detention, those months spent in darkness and solitude. 
ambiguously three different temporal and spatial events: the character being closed in the bunker, the indefiniteness of the situation deriving from a dream suddenly interrupted and the rapid awakening of the subject from sleep. The events follow a form of writing adjusted to the absurd experience, the temporal order is intentionally confusing and the different experiences are superimposed one onto the other in an estranging amalgam. Nevertheless, it is possible to get a logical order of events. If one positioned them on a temporal axis, there would be first the dream of the narrator, then the sudden entrance of the German soldiers in the barrack (where the narrator lives with the other female detainees) and, finally, the imprisonment and the solitude of the character in the bunker. The feeling of estrangement of the narrator is protracted until it mixes with the feeling of the reader: this device emphasizes the sense of loss of the Self and makes immediately perceptible (and absurd) the situation of the detainees in the camps.

Like the beginning by Semprun, the past is not proposed through the memory recalling events, but it is narrated as if it was lived and perceived in the present, in the same moment the 'witness' sees, feels and lives the facts. By this device, the figure of the 'narrator' is transformed into the figure of the 'observer' and the past is not anymore 'told', 'remembered', 'reconstructed', but it is described in a transparent manner. This rhetorical strategy allows to underline the 'truthfulness' of saying because the volatile experience is graved in an indelible way in the perception hic et nunc of the body and in the symmetric acknowledgment of the mind. According to Ricœur (2000: 731-747), this spontaneous evocation, this "presence of memory" is opposed to the difficult "search of memory" through which the memory is transformed into an image of something else that is no more existing and that, for this same reason, could be confused with a hallucination or, even worse, a pure fiction". Far from being commemorative, the "presence of memory" is, on the contrary,

\footnotetext{
9 According to Ricœur, "la problématique de la mémoire s'engage dans la voie périlleuse de la similitude, de la mimesis, qu'on n'a jamais fini de dissocier d'un côté du fantasme et de l'autre de l'image-copie, sans que puisse être rompu, d'un côté ou de l'autre, le sentiment d'un lien d'adéquation, de convenance de l'imagesouvenir à la chose souvenue [...]" (Ricœur 2000: 733).
} 
belonging to a "declarative" order and it presupposes an act of trust on the part of those who listen. ${ }^{10}$

Like in L'Écriture ou la vie by Semprun, also in La traversée de la nuit by De Gaulle Anthonioz the reaffirmation of identity threatened and weakened by the lack of points of references - passes through the body, although with a different modality compared to the one adopted by Semprun. In the case of De Gaulle Anthonioz, the subject becomes the perceptive receptacle of a negative synesthesia: the blinding light, the strong noise of the door slamming behind the prisoner's back, the staggering character, the bare walls, the roughness of the covers, the harshness of the voice contribute to create a melange of senses. Nevertheless, the loss of the Self is assimilated and strongly reconverted by the subject who suffers it through a surprising and unexpected mixture of dream and reality:

tout à l'heure je marchais sur un chemin éclairé par la lune, une lumière si douce, si bienfaisante, et des voix m'appelaient. (De Gaulle Anthonioz 1998: 9)

The negative experience of reality (to the point that it is lived as a "nightmare") is compared to another virtual experience (it is virtual because it is only dreamed) which proposes again a similar synesthesia, but inverted, as in a play of embellishing mirrors that reflect the positive aspects of a nightmare (the possibility to see thanks to the moonlight, the sweetness of the light, the friendly voices) as if the cognitive subject wanted to affirm obstinately her own threatened identity and re-establish a perceptive order ${ }^{11}$.

This positive approach to life, constitutive of a strong personality, is anticipated by the title through the reference to the crossing of the night (La traversée de la nuit). The 'crossing' is a temporary state of

10 In effect, Ricœur writes: “C'est alors que se propose, à l'orée de l'entreprise qui de la mémoire conduira à l'histoire, un acte de confiance dans une expérience qu'on peut tenir pour l'expérience princeps dans ce domaine, l'expérience de la reconnaissance" (Ricœur 2000: 733).

11 It is important to say that De Gaulle Anthonioz wrote this text in 1998 when she was 78 , that is fifty years after her painful experience. Furthermore, the strength to overcome the negative effects of life is confirmed by the determination through which she faces every obstacle. For example, she fought for ten years in order to have a law adopted against poverty. She succeeded in having the law voted in 1998. In addition to this, for a long time she deeply engaged as a permanent voluntary member in a humanitarian movement. 
imbalance that foresees a liquidation of this state and the acquisition of a positive state. A crossing is a spatial path including a beginning and an end. The excipit of the text coincides with the episode in which the main character gains her freedom from the concentration camp:

Nous échangeons un regard, nous n'osons nous parler encore, mais je lui tiens la main pour descendre les trois marches du bunker. Ensemble, encadrées des deux SS et de la surveillante, nous franchissons la porte du camp. Il y a encore de la neige, un vent glacé. J'essaie de me retourner et vois de loin les silhouettes courbées des femmes qui portent les lourds bidons de café. L'aube se lève à peine, c'est peut-être celle de l'espérance ? (De Gaulle Anthonioz 1998: 81-82)

This passage confirms once again the desire of the narrator to transform a negative experience in positive terms. As in a reflecting mirror, La traversée de la nuit opens and closes on the same, though inverted, elements. The conflicting situation of the beginning (the sudden and violent awakening and the isolation of the bunker) is dissolved in the excipit to the advantage of a quiet final scene in which the main character meets some other people with whom she finds mutual understanding and her internal world finds reconciliation with the surrounding external world. Giving up her feelings of estrangement and the fear to die, she welcomes an optimist attitude and hopes for the future. In the end, a situation of order (the "three steps", a "focus" on the subject) and a state of emotive peacefulness take over the cognitive loss of the subject and her perceptive disorder of the beginning (the negative synesthesia). Even though the final scene is still characterized by an absence of communication ("we dare not yet speak"), there is also evidence of other kinds of contact with other people and with the surrounding world: the hand of the fellow prisoner, the insistence on the comforting and exchanged look, the pleasant and reviving colour of the snow, the feeling of freshness coming from the blowing wind, the announcing brightness of dawn. All these elements can be seen both as a cognitive opening of the subject to the world and the rising hope of a new life. If in the incipit the subject crosses a spatial threshold that will isolate him from the rest of the world and place him in a narrow space of internal and external closing (the bunker, darkness, absence of contact with people), in the excipit the same subject crosses another threshold, opposed to the previous one, that takes him into an open and more 
powerful space: the door of the concentration camp corresponding to the acquisition of freedom and the end of a nightmare.

\section{Realism and historical truthfulness in Au temps des crématoires...}

After the analysis of the incipit by Semprun and by De Gaulle Anthonioz, here it is important to take into account a very different one: the incipit of Au temps des crématoires... by Jean Geoffroy. ${ }^{12}$ If in Semprun and in De Gaulle Anthonioz the situations were lived by the protagonists through a more subjective dimension, in Geoffroy the attempt is, on the contrary, to translate experiences in a more objective dimension. Both the author's intentions and the work's form point out a 'perspective of events' corresponding to a testimony of what the subject has lived and should be left as a trace of written memory:

Mon but est tout à fait modeste. Je n'ai pas même la prétention d'apporter la moindre contribution à l'histoire de cette tragique aventure.

Ce simple récit est destiné à mes camarades de Hradischko, aux familles de ceux qui ne sont pas revenus et à mes amis.

Je ne veux pas oublier. Pus tard, lorsque le temps aura fait son œuvre, je retrouverai quelques points de repère qui me permettront de me souvenir. (Geoffroy 2005: 8, Introduction)

In the introduction, the reader is informed that the 'discourse of truth' is the main purpose of the work: this truth is not connected to a 'scientific historical reconstruction', but it is based on a 'personal memory' that, for this reason, is even truer. The discourse of truth and the traces of memories to recover are seen jointly as the instruments to fix events.

This preoccupation for the "stabilisation of the material memory" (Assmann 1999: 277) is typical of man and culture and has to be investigated anthropologically in all its different declinations. From the semiotic viewpoint, it is also crucial to interrogate what are the

\footnotetext{
12 Jean Geoffroy was arrested in 1943 and deported first to Buchenwald, then to Flosenburg and finally to Hradischko. Geoffroy was freed in 1945, but he wrote Au temps des crématoires... two years after, in 1947, "not to forget...", as written in the epigraph.
} 
mechanisms that translate anthropological devices into concrete texts that, as a consequence, permit this stabilisation of memory. The close connections between anthropology and semiotics focus on some central questions. For example, where does memory place itself as a starting point in culture and texts? In which point of the temporal axis of experience can we insert the most important events to which the ensuing narrative material is hooked? As we have seen, the engraving of memory in the body and in immediate feelings is one of the most recurrent mechanisms used, among others, by Semprun and De Gaulle Anthonioz. In the case of Geoffroy, the possibility of stabilisation seems to be connected to the indispensable 'objective fixation of events' in space and time. This is why in Au temps des crématoires... begins with a precise foregrounding of the spatial and temporal context:

Le 7 août 1943, j'ai été arrêté par la Gestapo en gare d'Avignon. (Geoffroy 2005: 13)

There is no hint of subjective bewilderment, no trace of distorted or disoriented perception of events. There is not even a small evocation of the loss or recovery of identity. The reader has no element to get grasp of the horror existing in concentration camps. On the contrary, reality is manifested thanks to concrete points of temporal (day, month and year) and spatial (the Avignon train station) reference. The concrete anchorage and the clear positioning of some narrative facts remind some realist texts (Balzac, for example) or even some naturalist texts (Zola, for example). In this objective beginning, the different layers of reality and its natural development are analysed in a detached and rational way:

Avec quelques précautions, $\mathrm{j}$ 'aurais pu éviter cette fois de me faire prendre. Les avertissements ne m'avaient pas manqué. Léon Arnaud, chef du Centre Téléphonique d'Avignon, m'avait tenu au courant des investigations auxquelles la Gestapo s'était livrée dans mes fiches de communications interurbaines. Je quittais Avignon, mais j'eus le tort d'y revenir dans la nuit du 6 au 7 août. J'attendais le train de Grenoble vers 3 heures du matin, lorsque je constatai brusquement qu'un cercle s'était formé autour de moi, un cercle composé de messieurs élégants, à l'allure sportive, vêtus de clair. (Geoffroy 2005: 13)

It is certain that this incipit is not containing a strong emotive charge. As a consequence, the reader is not 'modelled' in the same way it is in the incipit by Semprun or De Gaulle Anthonioz. In Au temps des 
crématoires... by Geoffroy the reader is firmly anchored to a spatial and temporal dimension which is the outcome of a linear development of events. Nevertheless, this 'referential linearity' is tricky: the objectifying feature of the text is equally constructed by its author. The truthfulness of the story uttered by Geoffroy is the result of a complex figurative form that turns around the effective symbolic use of space. The narrator introduces, almost gradually, the reader into a universe of closure typical of concentration camps, starting from an initial narrowing of space ("un cercle s'était formé autour de moi"), a symbolic isolation that anticipates, as a sort of semantic prolexis, some features (for example, a physical and emotional oppression) characterizing life in concentration camps. This first closure is underlined by the insistence of the narrator on a parallel series of similar spatial seclusions: "la petite guérite où se tient habituellement l'employé qui retire les billets", the "poste de garde", the "prison de la caserme", the "cellule $n^{\circ} 6$ ", the "camion" that takes to the "train" and finally the concentration camp.

\section{Conclusion}

To show the complexity of histories of survival, I have underlined the centrality of a strategic place of texts: the incipit. I adopted a comparative perspective to stress similarities and differences in the incipit by Semprun, De Gaulle Anthonioz and Geoffroy. This perspective, both semiotic and anthropological, should be extended to other texts concerning histories of survival in order to extrapolate all theoretical outcomes out of this perspective. As a temporary conclusion, two points have to be briefly pointed out here.

Histories of survival amplify a dichotomy existing in several literary genres and currents: the categories of 'external reference' and 'internal organization'. Romanticism, Realism, Naturalism, Surrealism, etc., each of this current solves, in its own terms, this dichotomy based on mimetic 'truth' and on narrative 'structure', on 'reality' and 'convention', on 'experience' and 'narration'. My hypothesis is that histories of survival solve these oppositions by reconciling some contraries through the use of oxymora. Even narratives structures or key figures such as the author, the narrator, the observer, the witness and so on, tend to become oxymora. 
The second question that I have outlined in this contribution concerns the forms of uttering through which histories of survival are recalled to mind and written. These forms of uttering are, in my opinion, new and characterize the genre of histories of survival. It is in this kind of 'literature' that one can remark the effort of authors to face some oppositions by combining structural oxymora and new ways of uttering the event. The study of these features (and combination) is pertinent for anthropology (by seizing facts thanks to elaborated 'ways of uttering' authors often redefine forms of humanity) and for semiotics (any form of expression, even if original, has to be collectively shared and based on a system of signs). In my opinion, a joint semiotic and anthropological approach can help to better analyse histories of survival as a 'literary genre' and as a 'cultural negative phenomenon'.

\section{References}

Antelme, Robert 1948. Témoignage du camp et poésie. Le Patriote résistant 53. Assmann, Aleida 1999. Erinnerungsräume. Formen und Wandlungen des Kulturellen Gedächtnisses. München: C. H. Beck'sche Verlagsbuchhandlung. Coquio, Catherine 1998. L'homme-sans: poétique de l'indéterminé, histoire des exterminés. In: Deshoulières, Valérie-Angélique (ed.), Poétique de l'indéterminé. Clermont-Ferrand: Association des Publications de la Faculté des Lettres et Sciences Humaines de Clermont-Ferrand, 381-403.

- (ed.) 2003. L'Histoire trouée. Négation et témoignage. Nantes: Librairie l'Atalante.

De Gaulle Anthonioz, Geneviève 1998. La traversée de la nuit. Paris: Seuil.

Geoffroy, Jean 2005 [1947]. Au temps des crématoires... Clamecy: Nouvelle Imprimerie Labellery.

Levi, Primo 1963 [1947]. Se questo è un uomo. Torino: Einaudi.

Ricœur, Paul 2000. L'Écriture de l'histoire et la représentation du passé. Annales HSS 4: 731-747.

Rinn, Michael 1998. Les Récits du génocide. Sémiotique de l'indicible. Lausanne: Delachaux et Neistlé.

Sachso; d'Oranienburg-Sachsenhausen, Amicale 1982. Au cœur du système concentrationnaire nazi. Paris: Minuit.

Semprun, Jorge 1994. L'Écriture ou la vie. Paris: Gallimard.

Ternon, Yves 1999. Du négationnisme. Paris: Desclée de Brouwer.

White, Hayden 2006. Forme di storia. Dalla realtà alla narrazione (Testi riuniti da Edoardo Tortarolo). Roma: Carocci. 


\section{Как начинаются истории выживания: Начальные слова как стратегическое место для выражения невыразимого}

В статье анализируются истории людей, побывавших в концлагере: Де Голль Антониоз (La Traversée de la nuit), Жоффруа (Au temps des crématoires...) и Семпрун (L'Écriture ou la vie). Эти истории рассказывают о жизни выживших, но в то же время представляют и литературную форму, нарративная структура которой кодифицирует код самостоятельного жанра. Более детально я сосредотачиваюсь на введении - на стратегическом отрывке в тексте, в котором выявляются определенные черты общего значения и вся композиция текста. Я предполагаю, что в историях выживания авторы уже в начале стараются передать эмблематическую ценность своей истории: это пограничное и травматическое переживание, которое трудно выразить. Анализ выбранных введений показывает, что для выражения опыта концлагеря необходима определенная работа над формой выражения и художественные достоинства при передаче эти переживаний идут только на пользу. С точки зрения структуры произведения нарративы выживания расширяют уже существующие во многих литературных жанрах и течениях дихотомии: «внешняя референция» и «внутренняя организация», миметическая «правда» и нарративная «структура», «реальность» и «конвенция», «опыт» и «рассказ». По моему мнению, истории выживания решают эти противоречия, согласуя оппозиции с помощью оксюморона. Даже нарративные структуры и такие ключевые фигуры как автор, рассказчик, наблюдатель, свидетель и т.д. имеют склонность прератиться в оксюморон. Анализом названных составляющих (и их комбинаций) занимается как антропология так и семиотика. Антропология - поскольку авторы, осмысляя факты с помощью сложных способов высказывания, зачастую заново определяют понятие человечности. Семиотика - так как любой способ выражения, сколь бы он ни был оригинальным, всегда коллективен и основывается на какой-либо знаковой системе. Я считаю, что соединение антропологического и семиотического подхода позволяет анализировать истории выживания одновременно в качестве как «литературного жанра», так и «трагического события истории». 


\section{Kuidas saavad alguse ellujäämislood: Avasõnad kui strateegiline koht väljendamatu väljendamiseks}

Analüüsin käesolevas artiklis paari koonduslaagris elanud ja hiljem oma kogemusest rääkinud inimese lugusid: De Gaulle Anthonioz ( $\mathrm{La} \mathrm{Tra-}$ versée de la nuit), Geoffroy (Au temps des crématoires...), Semprun ( $L$ 'Écriture ou la vie). Need lood räägivad ellujääjate eludest, kuid samal ajal esindavad nad ka kirjandusvormi, mille narratiivne struktuur moodustab eraldi žanri koodi. Täpsemalt keskendun ma avasõnadele - strateegilisele lõigule tekstis, milles avalduvad teksti üldise tähenduse teatud jooned ja kogu teksti kompositsioon. Pakun välja, et ellujäämislugudes üritavad autorid juba avasõnadega edastada oma loo emblemaatilist väärtust: see on äärmuslik ja traumaatiline elamus, mida on raske väljendada. Valitud avalõikude analüüs näitab, et koonduslaagrielamuste väljendamiseks on vajalik teate sõnaosavus ning kunstilised kaalutlused tulevad nende kogemuste esitamisel ainult kasuks. Teose struktuuri seisukohast laiendavad ellujäämisnarratiivid paljudes kirjandusžanrides ja -vooludes juba eksisteerivaid dihhotoomiaid: "osutus" ja "sisemine organiseeritus", mimeetiline "tõde" ja narratiivne "struktuur", "reaalsus" ja "kokkuleppelisus", "kogemus" ja "jutustus". Minu arvates lahendavad ellujäämislood need vastuolud, lepitades vastaspoolused oksüümoroni kaudu. Isegi narratiivsetel struktuuridel ja sellistel võtmefiguuridel nagu autor, jutustaja, vaatleja, tunnistaja jne on kalduvus oksüümoroniks muutuda. Nimetatud elementide (ja nende kombinatsiooni) analüüs kuulub antropoloogia ja semiootika pädevusse. Antropoloogia valda, kuna keerukate väljendusmallide abil fakte mõtestades annavad autorid tihti inimlikkusele uue definitsiooni, ja semiootikasse, kuivõrd igasugune väljendusviis, ükskõik kui originaalne, on alati kollektiivne ning põhineb mingil märgisüsteemil. Arvan, et antropoloogilise ja semiootilise lähenemise ühendamine võimaldab ellujäämislugusid analüüsida üheaegselt nii "kirjandusžanri” kui "traagilise ajaloonähtusena". 
